CARADDE: Jurnal Pengabdian Kepada Masyarakat
$\begin{gathered}\text { https://journal.ilininstitute.com/index.php/caradde } \\ \text { Volume 2 | Nomor 2 | Februari | } 2020 \\ \text { e-ISSN: 2621-7910 dan p-ISSN: 2621-7961 }\end{gathered}$
DOI: https://doi.org/10.31960/caradde.v2i2.369

\title{
Pengabdian Kepada Masyarakat: Sinergitas Universitas dan Tentara Manunggal Membangun Desa (TMMD)
}

\section{Bahtiar Effendi}

\author{
Keywords : \\ Pengabdian Masyarakat; \\ Universitas Matana; TMMD; \\ Koperasi.
}

\section{Corespondensi Author}

Akuntansi, Fakultas Ekonomi, Bisnis dan Ilmu Sosial - Universitas Matana

Email: bahtiar.effendi90@gmail.com

\section{History Article}

Received: 20-Desember-2020;

Reviewed: 10-Januari-2019;

Accepted: 13-Januari-2020;

Avalaible Online: 19-Januari-2020;

Published: 14-Februari-2020;

\begin{abstract}
Abstrak. Kegiatan pengabdian kepada masyarakat ini bertujuan untuk meningkatkan pemahaman siswa/i terkait Koperasi, dan untuk menumbuhkan kesiapan serta motivasi siswa/i menerapkan Koperasi di kegiatan unit sekolah. Metode pelaksanaan kegiatan pengabdian kepada masyarakat dilakukan dalam beberapa tahap. Tahap pertama adalah perencanaan melalui observasi dan wawancara pendahuluan. Tahap kedua adalah pelaksanaan kegiatan berupa edukasi tentang koperasi dengan memaparkan materi, praktik penyusunan laporan Sisa Hasil Usaha (SHU) dan diskusi. Tahap ketiga adalah monitoring yang bertujuan untuk menampung permasalahan yang terjadi dan merumuskan solusi yang terbaik serta memantau perkembangan siswa/i dalam implementasi materi Koperasi. Analisis data yang digunakan adalah analisis deskriptif melalui wawancara dan survey langsung. Melalui post test yang dilakukan, ditemukan hasil sebanyak $87 \%$ siswa/i mampu dan mengerti menyelesaikan soal latihan terkait konsep dasar Koperasi secara "baik" dan 13\% siswa/i mampu dan mengerti menyelesaikan soal latihan terkait konsep dasar Koperasi secara "cukup". Selain itu, ada peningkatan kepercayaan diri siswa/i untuk mengembangkan Koperasi dalam kegiatan ekstrakurikuler sekolah. Informasi ini didapatkan dari hasil monitoring pasca pelatihan yang telah dilakukan.
\end{abstract}

\section{PENDAHULUAN}

Berdasarkan UU No. 12 Tahun 2012, Pasal 1 Ayat 9 dinyatakan bahwa Perguruan Tinggi wajib menyelenggarakan kegiatan Tridharma Perguruan Tinggi atau yang dikenal dengan Tridharma PT yang meliputi pendidikan dan pengajaran, penelitian, dan pengabdian kepada masyarakat. Sesuai peraturan tersebut, Universitas Matana melalui Biro Administrasi Akademik dan Kemahasiswaan (BAAK) serta Lembaga Penelitian dan Pengabdian Kepada
Masyarakat (LPPM) telah melaksanakan kegiatan Tridharma PT secara konsisten.

Salah satu keunggulan Universitas Matana adalah penerapan konsep RBTL (Research Based Teaching and Learning) yang dimulai pada tahun 2017. Konsep RBTL tersebut diimplementasikan dengan cara mengkolaborasikan antara kegiatan pendidikan dan pengajaran di kelas, pengabdian masyarakat dan kegiatan penelitian dengan melibatkan mahasiswa/i Universitas Matana untuk berperan serta aktif dalam menemukan permasalahan, 
merumuskan solusi dan evaluasi terkait dengan kegiatan pendidikan dan pengajaran yang sudah diterima di kelas guna perbaikan kurikulum dan metode pembelajaran secara terus menerus. Hal ini untuk mendekatkan konsep mata kuliah dengan realita kebutuhan di lapangan, terbukti lulusan Universitas Matana unggul dan terserap penuh di pasar tenaga kerja.

Konsep RBTL tersebut dibuktikan dengan keseriusan Univeritas Matana dalam beberapa kerjasama (MoU) dengan beberapa Desa Binaan atau Mitra Binaan, salah satunya adalah Mitra Binaan Desa Mekarwangi, Cisauk, Kabupaten Tangerang.

Adapun kegiatan pengabdian kepada masyarakat yang sudah terimplementasi dalam RBTL Program Studi Akuntansi Universitas Matana diantaranya Penguatan Kemampuan Bendahara dan Guru SD Melalui Pembelajaran Akuntansi Dasar di SDN Mekarwangi (Effendi, 2018); Peningkatan dan Penguatan SDN Mekarwangi, Cisauk, Tangerang Dalam Bentuk Pendampingan Akuntansi Untuk Bendahara dan Pengajar (Effendi, 2018); Penguatan Pemahaman Siswa Kelas XII AK Melalui Bimbingan dan Pelatihan Akuntansi dan Pajak di SMK Dharma Widya, Desa/ Kecamatan Neglasari, Tangerang-Banten (Effendi, 2018); Peningkatan Kesadaran Pelajar dengan Edukasi Konservasi Lingkungan Hidup di Sekolah Menengah Kejuruan Kesehatan Kharisma (Effendi, 2019); Edukasi dan Pendampingan Akuntansi Kader Posyandu Rambutan dan Posyandu Nusa Indah Desa Mekarwangi, Kabupaten Tangerang (2020).

TMMD (Tentara Manunggal Membangun Desa) merupakan program terpadu yang dilakukan oleh seluruh personel Tentara Nasional Indonesia dari semua matra kesatuan dalam rangka membantu pemerintah dalam akselerasi pembangunan masyarakat baik secara fisik maupun non fisik, pengembangan wilayah teritori dan pemberdayaan masyarakat yang difokuskan di pedesaan di seluruh wilayah negara kesatuan republik Indonesia (Nur, et.al., 2015).

Kegiatan TMMD bertujuan untuk meningkatkan kesejahteraan masyarakat guna membangun kemanunggalan atau keterpaduan antara TNI dengan masyarakat sekitar. Kegiatan TMMD menjadi Operasi Bhakti TNI yang dilaksanakan secara terpadu setiap tahun. Kegiatan ini mengedepankan kepentingan masyarakat dan juga peningkatan kegiatan gotong royong sebagai ciri khas Negara Kesatuan Republik Indonesia secara utuh. Dalam buku elektronik berjudul Perkembangan ABRI Masuk Desa 19801998 yang diterbitkan Avatara Universitas Negeri Surabaya, dituliskan Program AMD dicetuskan Jenderal M. Jusuf pada 1980 dengan tujuan membantu masyarakat dalam menyelesaikan setiap permasalahan. Lebih lanjut, AMD atau TMDD saat ini juga membantu memaksimalkan potensi desa, karena desa merupakan sumber penyuplai bahan-bahan baku pangan nasional serta sebagai sumber ketenagakerjaan.

Pemerintah Kabupaten Tangerang dan Kodim 0510/ Tigaraksa ikut serta andil dalam mensukseskan kegiatan tersebut melalui kegiatan fisik dan kegiatan non fisik. Khusus untuk kegiatan non fisik dilakukan melalui penyuluhan dan edukasi kepada sekolah-sekolah se-Kabupaten Tangerang yang berlangsung dari tanggal 10 juli hingga 08 agustus 2019. Sekolah merupakan tempat melahirkan perubahan tingkah laku manusia secara individu maupun kelompok melalui kegiatan pendidikan dan pengajaran guna membentuk manusia yang mampu menerapkan ilmu pengetahuan agama dan pengetahuan umum. Sekolah dijadikan objek kegiatan TMMD non fisik mengingat generasi penerus bangsa merupakan tonggak kuatnya suatu negara (Subianto, 2013).

Untuk tahun 2019 ini, Universitas Matana dipercaya sebagai salah satu Universitas yang diminta TNI dan Pemerintah Kabupaten Tangerang diantara Universitas-Universitas lain di Tangerang dalam membantu kegiatan non fisik TMMD 2019 melalui penyuluhan dan edukasi ke sekolah-sekolah se-Kabupaten Tangerang. Berdasarkan permintaan tersebut, Universitas Matana mengirimkan masing-masing perwakilan dosen dan mahasiswa dari 10 program studi yang terdiri atas program studi akuntansi, sistem komputer, teknik informatika, sistem informasi, fisika medis \& instrumentasi, manajemen, desain komunikasi visual, hospitality \& pariwisata, arsitektur dan statistika bisnis.

Program studi akuntansi universitas 
matana mendapatkan waktu untuk melakukan penyuluhan dan edukasi pada hari kamis tanggal 18 juli 2019 bertempat di SMK Kesehatan Kharisma, Panongan dengan fokus materi yang akan disampaikan sesuai dengan tema dan permintaan dari TMMD 2019 yakni perihal koperasi yang terbagi menjadi dua sesi dengan durasi dua jam setiap sesinya.

Materi yang menjadi fokus penyuluhan dan edukasi adalah tentang Koperasi. Materi ini disampaikan dengan latar belakang diadakannya kegiatan pengabdian masyarakat yakni masyarakat kabupaten Tangerang khususnya Sekolah belum memahami secara keseluruhan terkait dengan konsep, manfaat dan urgensi Koperasi, serta rendahnya praktik siswa/i dalam memanfaatkan secara optimal Koperasi yang ada di Sekolah.

SMK Kesehatan Kharisma sebagai salah satu sekolah kesehatan yang berlokasi di Panongan menjadi sasaran kegiatan TMMD yang dipercaya sebagai pilar untuk penerapan kegiatan Koperasi di sekolah tersebut. Pada dasarnya, sekolah ini telah memiliki kegiatan Koperasi yang pengelolaannya kurang maksimal sebagai salah satu unit kegiatan sekolah dengan kecenderungan rendahnya keterlibatan dan motivasi siswa/i dalam mengembangkan Koperasi. Selain itu, potensi Desapun mendukung apabila Koperasi dikelola dengan baik melalui hasil panen dan kerajinan masyarakat panongan dalam menjual hasil karya dan hasil aneka olahan pertanian yang dihasilkan.

SMK Kesehatan Kharisma (SMKS Kharisma) beralamat di Jalan Raya Korelet RT. 04/03, Desa Ranca Iyuh, Kecamatan Panongan, Kabupaten Tangerang, Provinsi Banten. SMK Kesehatan Kharisma ini memiliki beberapa konsentrasi jurusan yakni: kompetensi keahlian administrasi perkantoran, kompetensi keahlian farmasi, kompetensi keahlian keperwatan dan kompetensi keahlian teknik kendaraan ringan.

Adapun jarak tempuh antara Universitas Matana dengan lokasi kegiatan Pengabdian Masyarakat TMMD 2019 yakni SMK Kesehatan Kharisma Panongan adalah $16,9 \mathrm{Km}$ dan ditempuh dalam waktu kurang lebih 39 menit. Adapun detail lokasi disampaikan dalam Gambar 4 di atas.

Berdasarkan rekapitulasi data per 31
July 2019 yang diperoleh dari website resmi http://dapo.dikdasmen.kemdikbud.go.id untuk tenaga PTK (Guru ditambah dengan Tendik), PD (Peserta Didik), Sarpas dan Rombongan Belajar SMKS Kharisma Panongan akan ditunjukkan melalui Tabel 1 mengenai Data PTK dan PD, Tabel 2 mengenai Data Sarpas dan Tabel 3 mengenai Data Rombongan Belajar ditunjukkan berikut ini:

Tabel 1. Data PTK dan PD

\begin{tabular}{llcccc}
\hline No & Uraian & Guru & Tendik & PTK & PD \\
\hline \hline 1 & Laki-laki & 11 & 1 & 12 & 177 \\
2 & Perempuan & 12 & 1 & 13 & 257 \\
& TTL & $\mathbf{2 3}$ & $\mathbf{2}$ & $\mathbf{2 5}$ & $\mathbf{4 3 4}$ \\
\hline
\end{tabular}

Keterangan:

- Penghitungan jumlah PTK adalah yang sudah mendapat penugasan, berstatus aktif dan terdaftar di sekolah induk.

- Singkatan :

1. PTK = Guru ditambah Tendik

2. $\mathrm{PD}=$ Peserta Didik

Tabel 1 di atas menjelaskan posisi per 31 July 2019 jumlah Guru sebanyak 23 orang, jumlah tenaga pendidik sebanyak 2 orang, sehingga jumlah PTK sebanyak 25 orang, dan jumlah Peserta Didik (PD) sebanyak 434. Apabila kita analisa, setiap 1 guru memberikan pendidikan dan pengajaran kepada 18 siswa/i. Hal ini masih dikatakan ideal karena masih dalam total normal, idealnya jumlah maksimal siswa yang diampu oleh 1 guru adalah 28 siswa.

Data sarana dan prasarana sekolah (Sarpras) ditunjukkan dalam Tabel 2 di bawah ini. Berdasarkan tabel 2, dapat dijelaskan bahwa per tanggal 31 July 2019 untuk ruang kelas berjumlah 11 kelas, namun sayangnya untuk ruang laboraturium dan ruang perpustakaan belum didaftarkan dan diupdate di data kemendikbud padahal realnya, kedua ruang tersebut tersedia dan sudah digunakan oleh siswa/i.

Tabel 2. Data Sarpas

\begin{tabular}{llc}
\hline No & Uraian & Jumlah \\
\hline \hline 1 & Ruang Kelas & 11 \\
2 & Ruang Lab & 0 \\
3 & Ruang Perpus & 0 \\
& TTL & $\mathbf{1 1}$ \\
\hline \multicolumn{2}{c}{ Sumber: dikdasmen kemendikbud }
\end{tabular}


Caradde: Jurnal Pengabdian Kepada Masyarakat

Vol 2 No 2, Februari 2020

Perihal rombongan belajar, SMK Kesehatan Kharisma Panongan per tanggal 31 July 2019 disampaikan pada Tabel 3 berikut ini:

Tabel 3. Data Rombongan Belajar

\begin{tabular}{ccccc}
\hline No & Uraian & $\begin{array}{c}\text { Jml } \\
(\mathrm{L})\end{array}$ & $\begin{array}{c}\text { Jml } \\
(\mathrm{P})\end{array}$ & Total \\
\hline \hline 1 & Kelas 10 & 44 & 56 & 100 \\
2 & Kelas 11 & 65 & 100 & 165 \\
3 & Kelas 12 & 68 & 101 & 169
\end{tabular}

Sumber: dikdasmen kemendikbud

Berdasarkan Tabel 3 di atas, dapat dijelaskan bahwa jumlah data rombongan belajar per 31 july 2019 untuk kelas 10 sebanyak 100 siswa yang terdiri atas 44 siswa laki-laki dan 56 siswi perempuan. Kelas 11 mengalami peningkatan sebanyak 65 siswa dengan total 165 siswa yang terdiri atas 65 siswa laki-laki dan 100 siswi perempuan. Terakhir, untuk kelas 12 jika dibandingakan dengan kelas 11 mengalami peningkatan sebanyak 4 siswa dengan total sebanyak 169 siswa yang terdiri atas 68 siswa laki-laki dan 101 siswi perempuan.

Selanjutnya, untuk kompetensi keahlian di SMKS Kharisma terdiri atas kompetensi keahlian administrasi perkantoran, kompetensi keahlian farmasi, kompetensi keahlian keperwatan dan kompetensi keahlian teknik kendaraan ringan.

Rumusan masalah yang akan dipecahkan dalam kegiatan pelatihan Koperasi ini adalah: (1) Sejauh mana pemahaman siswa/i terkait Koperasi?; (2) Sejauh mana kesiapan dan motivasi siswa/i mengimplementasikan Koperasi di kegiatan unit sekolah?. Adapun tujuan dari kegiatan pelatihan Koperasi ini adalah: (1) Untuk meningkatkan pemahaman siswa/i terkait Koperasi; (2) Untuk menumbuhkan kesiapan dan motivasi siswa/i mengimplementasikan Koperasi di kegiatan unit sekolah.

Pelatihan merupakan suatu proses dimana orang-orang mencapai kemampuan tertentu untuk membantu mencapai tujuan organisasi. Oleh karena itu, proses ini terikat dengan berbagai tujuan organisasi, pelatihan dapat dipandang secara sempit maupun luas (Mathis, 2002). Pelatihan dipandang perlu dalam kegiatan pengabdian masyarakat dimana tujuan dalam kegiatan pelatihan ini adalah untuk meningkatkan kemampuan peserta dalam mengimplementasikan suatu hal yang menjadi materi dalam pelatihan. Adapun fokus dalam kegiatan pelatihan TMMD 2019 di SMK Kesehatan Kharisma, Panongan, Tangerang adalah mengenai konsep dasar, manfaat dan urgensi koperasi. Adapun tujuannya, adalah untuk meningkatkan pemahaman siswa/i SMK Kesehatan Kharisma Panongan perihal Koperasi dan menumbuhkan kesiapan dan motivasi untuk berperan serta aktif di Koperasi Sekolah.

Koperasi secara umum terdiri atas sekumpulan orang yang secara sukarela memiliki tujuan yang sama untuk meningkatkan kesejahteraan mereka dimana dengan sumber pendanaan dari diri anggota untuk kepentingan anggota secara adil dan demokratis. Menurut pendapat Arifin Sitio dan Halomoan Tamba (2001: 18) menyatakan bahwa koperasi merupakan organisasi tolong menolong yang menjalankan "urus niaga" secara kumpulan, yang berazazkan konsep tolong menolong. Aktivitas dalam urusniaga semata-mata bertujuan ekonomi, bukan sosial seperti yang dikandung gotong royong.

Peran koperasi sekolah dipandang penting dalam pelaksanaan pembangunan ekonomi. Perkembangan suatu sekolah akan lebih cepat apabila koperasi menjadi perantara dalam pembelajaran siswa/i sekolah sebagai upaya pelatihan bagi siswa/i dalam mengimplementasikan semangat berwirausaha, bekerja sama dan mampu menjadi entrepreneur muda guna mewujudkan ide-ide baru dalam kegiatan nyata setiap kegiatan usaha. Melalui koperasi, siswa/i akan terlatih dalam bergotong royong, kerjasama tim antar anggota pengurus koperasi dan memecahkan setiap permasalahan yang dihadapi oleh Koperasi yang tentu menjadikannya bekal dalam melangkahkan kaki di dunia kerja nyata. Kegiatan koperasi sekolah merupakan kegiatan yang bersifkat kontinue (Afsari, 2013).

\section{METODE}

Objek kegiatan pengabdian masyakat dengan judul "Pengabdian Kepada Masyarakat Dalam Sinergitas Universitas dan TMMD Ke-15 Wilayah Kodim 0510/ Tigaraksa di Kabupaten Tangerang, Banten" 
dilaksanakan di SMK Kesehatan Kharisma, Panongan, Kabupaten Tangerang.

Teknik pengumpulan data dilakukan dengan menggunakan survey dan wawancara lapangan serta teknik analisa data yang digunakan dengan menggunakan teknik analisis deskriptif guna memecahkan permasalahan yang dihadapi sekolah tersebut tentu dengan hasil pelatihan yang dilakukan dan merumuskan solusi terbaik guna percepatan pembangunan masyarakat sesuai dengan misi kegiatan non fisik TMMD 2019 khususnya di SMKS Kharisma. Materi yang disampaikan disesuaikan dengan kondisi dan kebutuhan yang ada di Sekolah ini.

Pengumpulan data dilakukan melalui tahap survey dan wawancara langsung kepada siswa/i SMK Kesehatan Kharisma, Panongan dalam kegiatan pelatihan ini dengan konsep penyusunan menggunakan dua pendekatan yakni pendekatan pemahaman dan pendekatan implementasi.

Pendekatan pertama (pemahaman) terdiri atas analisa kemampuan setiap siswa/i dengan melakukan tanya jawab langsung sebelum kegiatan pelatihan dimulai kepada siswa/i yang tersebar di setiap perwakilan kompetensi masing-masing 5 siswa dengan predikat sebagai berikut: (1) sebanyak 2 siswa dengan nilai terbaik dari masing-masing kompetensi keahlian, (2) sebanyak 1 siswa dengan nilai sedang, dan (3) sebanyak 2 siswa dengan nilai rendah. Sehingga apabila dihitung dari empat kompetensi keahlian telah diperoleh 20 siswa dengan konten pertanyaan terkait pemahaman arti penting dari Koperasi, apakah tujuan dibentuknya Koperasi dan terakhir, manfaat apa saja yang diperoleh dari kegiatan Koperasi bagi masyarakat.

Tahap pertama (pemahaman) ini dikenal dengan istilah pretest. Setelah mengetahui cluster dari masing-masing kelas maka kegiatan pelatihan disusun dengan materi yang mementingkan keseragaman pemahaman antar peserta pelatihan. Jadi, materi dimodifikasi dan disusun agar semua peserta pelatihan Koperasi dapat memahami secara keseluruhan.

Pendekatan kedua (implementasi) terdiri atas kegiatan melakukan simulasi pembentukan koperasi di masing-masing kelas terdapat kelompok siswa yang bertanggungjawab sebagai pengelola (anggota koperasi) maupun sebagai masyarkat selaku peminjam dana maupun masyarakat sebagai pihak yang menyediakan barang-barang hasil olahan pertanian dan kerajinan tangan untuk dititipkan di Koperasi.

Adapun detail dari pelaksanaan kegiatan pelatihan Koperasi ini bersifat insidental karena hanya diberikan waktu oleh Pemerintah Kabupaten Tangerang dan TNI Kodim 0510/Tigaraksa hanya satu hari dengan rincian agenda pelatihan ditunjukkan melalui Tabel 4 sebagai berikut:

Tabel 4. Agenda Pelatihan Koperasi

\begin{tabular}{|c|c|}
\hline Hari/ Tanggal & Kamis/18 Juli 2019 \\
\hline Pukul & $10.00-12.30 \mathrm{WIB}$ \\
\hline Peserta & $\begin{array}{l}53 \text { siswa dari masing- } \\
\text { masing perwakilan siswa } \\
\text { kelas XII. }\end{array}$ \\
\hline Tempat & $\begin{array}{l}\text { SMK Kesehatan Kharisma, } \\
\text { Ds. Ranca Iyuh, Kec. } \\
\text { Panongan, Kabupaten } \\
\text { Tangerang-Banten. }\end{array}$ \\
\hline Agenda & $\begin{array}{l}\text { Pelatihan Koperasi, UKM } \\
\text { dan Implementasi CSR } \\
\text { (Lingkungan Hidup) }\end{array}$ \\
\hline Instruktur & $\begin{array}{l}\text { Dosen Pembina: } \\
\text { Bahtiar Effendi, S.E., } \\
\text { M.Ak., CSRS., CSP. }\end{array}$ \\
\hline & $\begin{array}{l}\text { Mahasiswa: } \\
\text { Nadia Theresiady, Delvia, } \\
\text { Selly Tricia, Jessica dan } \\
\text { Raynanda. }\end{array}$ \\
\hline
\end{tabular}

\section{HASIL DAN PEMBAHASAN}

\section{Kegiatan Tentara Manunggal}

Membangun Desa (TMMD) Tahun 2019 didukung melalui keterlibatan institusi universitas dalam bentuk kegiatan pengabdian masyarakat Program Studi Akuntansi Universitas Matana. Adapun tujuan terpenting dari kegiatan pengabdian masyarakat yang dilakukan adalah akselerasi dan percepatan pembangunan masyarakat tertinggal Kabupaten Tangerang khususnya di Desa Ranca Iyuh melalui kegiatan pelatihan Koperasi bagi para siswa/i kelas XII SMK Kesehatan Kharisma, Panongan.

Siswa/i kelas XII yang menjadi peserta pelatihan ini terdiri atas siswa/i dari berbagai kompetensi keahlian. Jumlah siswa/i peserta pelatihan yang hadir 
berjumlah 53 siswa/i yang terdiri atas siswa/I kelas XII kompetensi keahlian administrasi perkantoran sebanyak 18 siswa/i, siswa/i kelas XII kompetensi keahlian farmasi sebanyak 13 siswa/i, siswa/i kelas XII kompetensi keahlian keperawatan sebanyak 9 siswa/i dan siswa/i kelas XII kompetensi keahlian teknik kendaraan ringan sebanyak 13 siswa/i. Proses pelatihan yang dikemas dalam dua sesi waktu (pagi dan siang) berjalan dengan lancar dan fokus dengan prosentasi kehadiran mencapai $100 \%$. Pada saat proses pelatihan berlangsung, terlihat semangat antusias dari para siswa/i dalam mengikuti kegiatan pelatihan. Ditemukan adanya beberapa siswa/i yang mengutarakan berbagai pertanyaan yang dilontarkan terkait mekanisme koperasi.

Proses tanya jawab serta penjelasan atas jawaban pertanyaan dari siswa/i peserta pelatihan koperasi ditunjukkan melalui Gambar 5 di bawah ini:

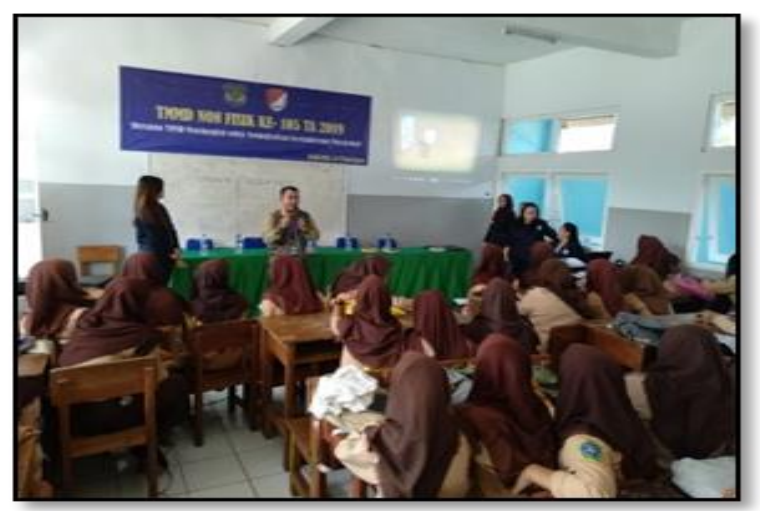

Gambar 5. Suasana Tanya Jawab \&

Penjelasan Jawaban Pertanyaan

Peserta Pelatihan

Adapun suasana pembelajaran Koperasi sendiri, mahasiswa sebagai asisten instruktur memaparkan manfaat, cara pengelolaan, cara perhitungan SHU, dan seputar iuran yang dibebankan kepada anggota Koperasi dengan penambahan implementasi pendirian Koperasi dalam meningkatkan kesejahteraan baik anggota maupun masyarakat sekitar. Suasana pemaparan materi Koperasi oleh asisten instruktur dijelaskan pada Gambar 6 di bawah ini:
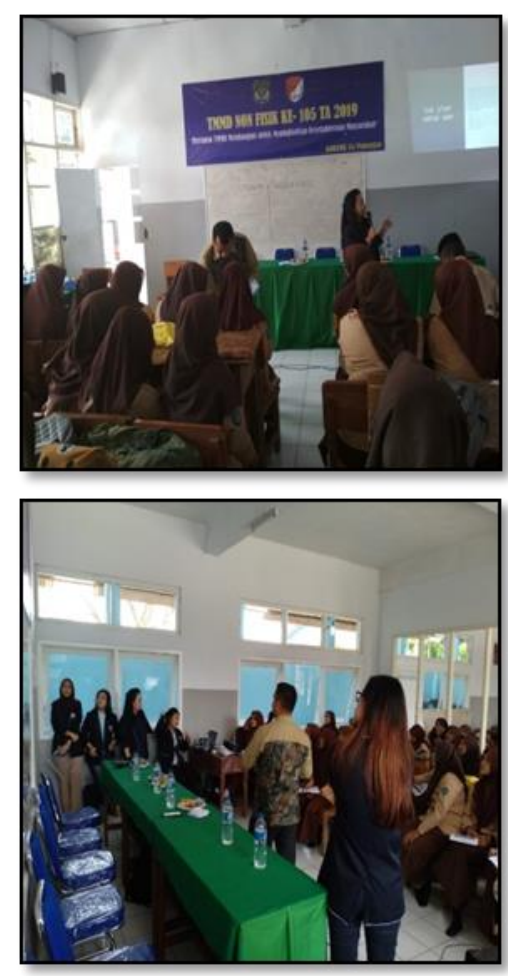

Gambar 6. Suasana Pemaparan Materi oleh Instruktur dan Asisten Instruktur

Selanjutnya, menjelang akhir penjelasan materi, dibentuklah simulasi Koperasi mini dengan peserta yang diacak dari beberapa konsentrasi keilmuan untuk mempraktikan pengelolaan koperasi, manfaat yang diperoleh, cara pemungutan iuran anggota, pembukuan dana koperasi dan pembagian SHU. Jadi, para siswa/i peserta pelatihan koperasi dapat memahami secara keseluruhan korelasi antara pembentukan dan urgensi serta manfaat Koperasi khususnya dalam kegiatan unit sekolah SMK Kesehatan Kharisma, Panongan.

Kegiatan pelatihan Koperasi dilakukan selama kurun waktu 4 jam (menyesuaikan dari permintaan TNI sebagai penyelenggara TMMD) mengingat banyaknya pemateri yang akan menyampaikan dalam kegiatan TMMD diantaranya: POLRI, TNI, Dinas Pertanahan, Dinas Pertanian, Dinas Kehutanan, dan beberapa Institusi yang terlibat dalam kegiatan TMMD Tahun 2019 ini.

Diakhir waktu penutup (setengah jam sebelum waktu berakhir) dilakukan adanya evaluasi post-test untuk mengukur tingkat pemahaman dari siswa/i pelatihan mengenai materi Koperasi yang telah disampaikan.

Proses evaluasi post-test tersebut 
dilakukan melalui penyebaran soal latihan yang harus dikerjakan oleh siswa/i yang meliputi soal konsep dasar, manfaat dan urgensi koperasi dan beberapa pertanyaan lisan yang diberikan dan wajib dijawab oleh beberapa perwakilan siswa/i yang terpilih dari berbagai konsentrasi keilmuan (setiap konsentrasi keilmuan diwakili oleh dua orang siswa/i).

Berdasarkan analisa hasil evaluasi (post-test) baik dari hasil proses pengerjaan soal latihan secara tertulis maupun penarikan kesimpulan melalui pertanyaan lisan diskusi yang telah dilakukan, diperoleh hasil sebagai berikut:

- Sebanyak $\mathbf{8 7 \%}$ siswa/i peserta pelatihan mampu dan mengerti menyelesaikan soal latihan baik secara tertulis maupun secara lisan terkait konsep dasar, manfaat dan urgensi koperasi secara "baik";

- Sebanyak $13 \%$ siswa/i peserta pelatihan mampu dan mengerti menyelesaikan soal latihan baik secara tertulis maupun secara lisan terkait konsep dasar, manfaat dan urgensi koperasi secara "cukup".

Selain daripada evaluasi (post-test) yang telah dilakukan, kegiatan pelatihan inipun diakhiri dengan adanya penyebaran kuesioner monitoring feed-back pelaksanaan pelatihan yang telah dilakukan kepada 15 siswa/i kelas XII selaku responden peserta pelatihan Koperasi yang tersebar atas beberapa konsentrasi keilmuan. Adapun hasil rekap dari kuesioner feed-back pelaksanaan pelatihan tersebut dapat dilihat dalam Tabel 5 berikut ini:

Tabel 5. Hasil Rekap Kuesioner "Feedback Pelaksanaan Pelatihan Koperasi"

\begin{tabular}{|c|c|c|c|c|c|c|}
\hline \multicolumn{2}{|r|}{ Pernyataan } & $\begin{array}{c}\text { Sangat } \\
\text { Tidak } \\
\text { Setuju }\end{array}$ & $\begin{array}{l}\text { Tidak } \\
\text { Setuju }\end{array}$ & Setuju & $\begin{array}{l}\text { Sangat } \\
\text { Setuju }\end{array}$ & $\begin{array}{c}\text { Total } \\
\text { Responden }\end{array}$ \\
\hline \multicolumn{7}{|c|}{ PEMBICARA } \\
\hline 1. & Menguasai materi & 0 & 2 & 12 & 1 & 15 \\
\hline 2. & Komunikasi \& menarik & 0 & 3 & 11 & 1 & 15 \\
\hline 3. & Presentasi audiovisualnya menarik & 0 & 1 & 12 & 2 & 15 \\
\hline 4. & Memberi kesempatan untuk diskusi & 0 & 4 & 6 & 5 & 15 \\
\hline \multicolumn{7}{|c|}{ MATERI } \\
\hline 5. & Bermanfaat & 0 & 0 & 14 & 1 & 15 \\
\hline 6. & Cakupan materinya memadai & 0 & 2 & 10 & 3 & 15 \\
\hline 7. & Sesuai dengan perkembangan & 0 & 3 & 11 & 1 & 15 \\
\hline \multicolumn{7}{|c|}{ SUASANA } \\
\hline 8. & Membosankan & 1 & 8 & 5 & 1 & 15 \\
\hline 9. & Peserta aktif & 0 & 2 & 13 & 0 & 15 \\
\hline & Tepat waktu & 0 & 6 & 8 & 1 & 15 \\
\hline
\end{tabular}

Berdasarkan Tabel 5 di atas tentang hasil feed-back peserta pelatihan Koperasi dapat disimpulkan bahwa sebagian besar peserta menyatakan bahwa dari aspek materi: $85 \%$ pembicara menguasai materi dengan baik, komunikasi pembicara menarik, presentasi audiovisiual juga menarik, serta pembicara memberikan kesempatan kepada peserta pelatihan untuk diskusi. Dari aspek materi yang disampaikan: sebagian besar peserta $98 \%$ menyatakan bahwa materi yang disampaikan cukup bermanfaat, cakupan materi yang disampaikan sangat memadai dan materi sesuai dengan perkembangan saat ini. Terakhir, dari aspek suasana $75 \%$ peserta menyatakan bahwa suasana pelatihan tidak membosankan, peserta aktif dalam berdisuksi dan memperhatikan dari setiap pemaparan materi pelatihan dan pelaksanaan pelatihan mayoritas peserta menyatakan tepat waktu.

Peningkatan kesiapan dan motivasi siswa/i mengimplementasikan Koperasi di kegiatan unit sekolah SMK Kesehatan Kharisma, Panongan tergambar sebagaimana yang telah ditunjukkan dalam Gambar 8. di atas.

Pada sesi terakhir, kegiatan pelatihan ditutup dengan foto bersama antara Kepala TNI, Kepala Polri, Kepala Dinas Pertanian, Dosen dan Mahasiswa Universitas Matana, Dewan Guru SMK Kesehatan KharismaPanongan, dan Beberapa Perwakilan Siswa/i Peserta Pelatihan Koperasi. Sesi foto bersama sesuai dengan yang ditunjukkan dalam Gambar 6 berikut ini:

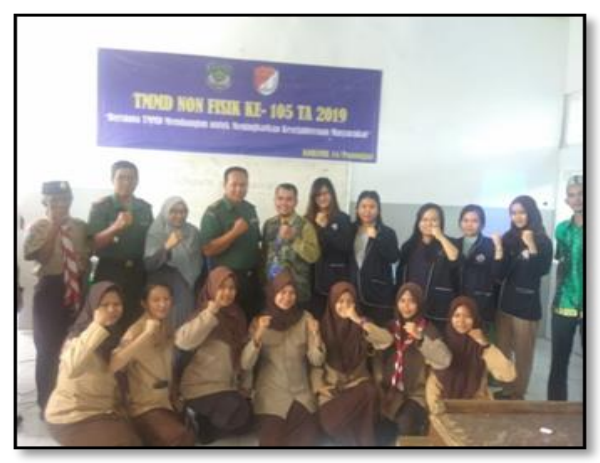

Gambar 6. Sesi Foto Bersama TMMDUniversitas Matana

\section{SIMPULAN DAN SARAN}

Kegiatan pengabdian masyarakat
dalam sinergitas Universitas Matana dan
TMMD ke-15 Wilayah Kodim 0510/
Tigaraksa di Kabupaten Tangerang, Banten
melalui pelatihan Koperasi bagi siswa/i kelas
XII yang tersebar dari kompetensi
administrasi perkantoran, kompetensi


Caradde: Jurnal Pengabdian Kepada Masyarakat Vol 2 No 2, Februari 2020

farmasi, kompetensi keperawatan dan kompetensi teknik kendaraan ringan mendapatkan kesan yang baik dari siswa/i peserta dengan dibuktikan dari prosentasi kehadiran peserta mencapai $100 \%$ dan berdasarkan hasil kuesioner yang diisi oleh peserta pelatihan mengharapkan agar kegiatan pelatihan ini dapat dilakukan secara berkelanjutan tidak hanya di sekolah namun di masyarkat sekitar Kecamatan Panongan.

Peserta pelatihan Koperasi diikuti oleh 53 siswa/i yang terdiri dari perwakilan siswa kelas XII dari masing-masing kompetensi keahlian terdiri atas 18 siswa/i (kelas XII kompetensi administrasi perkantoran), 13 siswa/i (kelas XII kompetensi farmasi), 9 siswa/i (kelas XII kompetensi keperawatan) dan 13 siswa/i (kelas XII kompetensi teknik kendaraan ringan).

Analisa yang telah dilakukan dari hasil evaluasi (post-test) pengerjaan soal latihan baik secara tertulis maupun secara lisan, diperoleh hasil bahwa terdapat peningkatan pemahaman bagi para Siswa/i peserta pelatihan dalam menyelesaikan soal latihan terkait konsep dasar, manfaat dan urgensi koperasi dan peningkatan kesiapan dalam berperan aktif mengelola Koperasi di SMKS Kharisma, Panongan.

Adapun saran untuk kegiatan pengabdian kepada masyarakat selanjutnya, diharapkan dapat menambah tools dalam mempraktikan praktek Koperasi dan durasi pelatihan yang lebih panjang dengan merubah sifat pelatihan dari insidental menjadi terjawal rutin agar output kegiatan pengabdian kepada masyarakat lebih maksimal.

\section{DAFTAR RUJUKAN}

Afsari, Nining. (2013). Upaya Meningkatkan Partisipasi Berkoperasi Sekolah Melalui Pelatihan Bagi Siswa Kelas XI SMK Wikarya Karanganyar Tahun Ajaran 2012/2013 (Studi Pada Koperasi Sekolah SMK Wikarya Karanganyar), Naskah Publikasi, Universitas Muhammadiyah Surakarta.

Arifin, S., Halomoan, T., (2001), Koperasi : Teori dan Praktik, Jakarta : Erlangga.

Effendi, B. (2018). Penguatan Kemampuan Bendahara dan Guru SD Melalui
Pembelajaran Akuntansi Dasar di SDN Mekarwangi, Ds. Mekarwangi, Kec. Cisauk, Tangerang-Banten, Jurnal Terapan Abdimas, (Online), Jilid 3, No.2, hlm. 188-191.

Effendi, B. (2018). Accounting Assistance for Treasurers and Teachers for Improvement and Strengthening of Mekarwangi Elementary School, Cisauk, Tangerang [Peningkatan dan Penguatan SDN Mekarwangi, Cisauk, Tangerang Dalam Bentuk Pendampingan Akuntansi Untuk Bendahara dan Pengajar], Proceeding of Community Development, (Online), Jilid 2, hlm. 225-233.

Effendi, B. (2018). Penguatan Pemahaman Siswa Kelas XII AK Melalui Bimbingan dan Pelatihan Akuntansi dan Pajak di SMK Dharma Widya, Desa/ Kecamatan Neglasari, Tangerang-Banten, International Journal of Community Service Learning, (Online), Jilid 2, No. 4, hlm. 302-308.

Effendi, B. (2019). Peningkatan Kesadaran Pelajar dengan Edukasi Konservasi Lingkungan Hidup di Sekolah Menengah Kejuruan Kesehatan Kharisma, Jurnal Pemberdayaan Masyarakat: Media Pemikiran dan Dakwah Pembangunan, (Online), Jilid 3, No.2.

https://doi.org/10.14421/jpm.2019.03 $\underline{2-04}$

Effendi, B. (2020). Edukasi dan Pendampingan Akuntansi Kader Posyandu Rambutan dan Posyandu Nusa Indah Desa Mekarwangi, Kabupaten Tangerang, Amalee: Indonesian Journal of Community Research \& Engagement, (Online), Jilid 1, No.1.

Kementerian Pendidikan dan Kebudayaan tentang Rekapitulasi Data Pokok Pendidikan Nasional, (http://dapo.dikdasmen.kemdikbud.go. id, diakses 05 Januari 2020).

Mathis, R.L. (2002). Manajemen Sumber Daya Manusia, Salemba: Jakarta.

Nur, M.A., Sadiki, A. dan Saepudin, A. (2015). Upaya Edukatif Pada Program 
Tentara Manunggal Membangun Desa

(TMMD) Dalam Meningkatkan

Partisipasi Masyarakat (Studi Deskriptif

Dalam Pembangunan Jalan Di Desa

Sukamaju Kecamatan Cimaung

Kabupaten Bandung), Jurnal Pendidikan

Luar Sekolah, (Online), Jilid 11, No. 2.

Subianto, Jito. (2013). Peran Keluarga, Sekolah dan Masyarakat Dalam Pembentukan Karakter Berkualitas, Edukasia: Jurnal Penelitian dan Pendidikan Islam, Jilid 8, No. 2.

Undang-Undang Republik Indonesia Nomor 12 tahun 2012 tentang Perguruan Tinggi. 